Hikmah: Journal of Islamic Studies, 17 (2), 2021, 86-100

http://journal.uinjkt.ac.id/index.php/HIKMAH

DOI: 10.47466/hikmah.v17i2.199. | P-ISSN. 2088-2629, E-ISSN. 2581-0146

\title{
ANALISIS DESKRIPTIF METODE ISTINBAT HUKUM MAJELIS ULAMA INDONESIA (MUI)
}

\author{
Mustori \\ UIN Syarif Hidayatullah Jakarta, Indonesia \\ musthoryahmad@gmail.com
}

\begin{abstract}
Majelis Ulama Indonesia (MUI)/The Council of Indonesia Ulama a body of muslim scholars established by the Indonesia government as the channel of communication to the society. One of MUI's task and authority is delivering the fatwa (Islamic legal opinion) to the need individually or institutionally. Legal problems addressed to MUI varied, ranging from private to public ones. In term of that, MUI compiled the guidance of fatwa establishment. It is based on Decision Letter of Board Leader of Majelis Ulama Indonesia, Number: U-596/MUI/X/1997. It is stated in the guidance of fatwa that every fatwa is legal opinion based on high authoritative law and bring the goodness (maslahah) to people. The basic principles in determining fatwa are al-Qur'an, hadith, Ijmak (consensus), qiyas (analog), and others principles of law.
\end{abstract}

Keywords: Method; Fatwa; Council of Indonesia Ulama

\begin{abstract}
Abstrak
Majelis Ulama Indonesia (MUI) merupakan lembaga yang dibentuk oleh pemerintah dengan fungsi sebagai saluran komunikasi umat Islam. MUI memiliki sejumlah tugas dan wewenang, salah satunya adalah memberikan fatwa bagi orang yang membutuhkannya, baik yang bersifat individual ataupun lembaga pemerintahan. Permasalahan yang diajukan kepada MUI untuk dimintai fatwa pun beragam, baik masalah pribadi bahkan masalah publik. MUI telah menyusun pedoman penetapan fatwa sebagai acuan dalam memutuskan suatu permasalahan, sebagaimana tercantum dalam Surat Keputusan nomor: U596/MUI/X/1997. Dalam pedoman ini dikatakan bahwa setiap fatwa yang dikeluarkan harus berupa pendapat hukum yang didasarkan oleh dalil-dalil yang paling kuat, serta membawa kemaslahatan bagi umat. Dasar-dasar yang dijadikan pegangan dalam penetapan fatwa adalah al-Qur'an, hadits, ijmak, kiyas, dan dasar-dasar hukum lainnya.
\end{abstract}

Kata Kunci: Metode; Fatwa; Majelis Ulama Indonesia 


\section{PENDAHULUAN}

Fatwa merupakan jawaban/penafsiran terhadap pertanyaan-pertanyaan berkaitan dengan hukum Islam yang diajukan oleh mustafti kepada seorang mufti. Dalam bahasa Arab fatwa dapat diartikan sebagai nasehat, jawaban, petuah, dan pendapat seorang mufti. Secara istilah fatwa dapat diartikan sebagai jawaban atau nasehat resmi yang dibuat oleh suatu lembaga atau individu sebagai jawaban atau penjelasan terhadap suatu pertanyaan yang diajukan oleh seorang pemohon fatwa (mustafti) kepada mufti atau ulama yang berwenang. Di Indonesia, lembaga fatwa yang digunakan sebagai pedoman dalam kehidupan beragama yaitu fatwa-fatwa yang dikeluarkan oleh Majelis Ulama Indonesi (MUI). Menjadi seorang mufti bukanlah hal yang mudah, membutuhkan berbagai persyaratan yang ketat, dan di samping itu, permasalahan-permasalahan yang muncul semakin kompleks, baik masalah keagamaan, ataupun masalah non-keagamaan, seperti masalah sosial budaya, ekonomi dan politik, sehingga ijtihad secara individual dirasa tidak memungkinkan lagi. ${ }^{1}$

Kondisi objektif masalah kemanusiaan terus berkembang dan bermunculan seiring dengan perkembangan zaman. Hal ini memerlukan respons hukum yang berlandaskan pada nass al-Qur'an dan sunah. Ijtihad dengan kriteria tertentu diperlukan untuk menjawaban berbagai permasalahan-permasalahan yang muncul dengan tetap menggunakan al-Qur'an dan sunah sebagai sumber referensi utama. Bagi seorang yang tidak dapat melakukan istinbat hukum secara mandiri, dan ia membutuhkan jawaban atas suatu permasalahan dapat menempuh jalan dengan meminta fatwa kepada seorang mufti. Fatwa memiliki sejumlah urgensivitas, di antaranya adalah sebagai respons terhadap perkembangan permasalahan yang bersifat kontemporer, di samping sebagai solusi atas pertanyaan-pertanyaan yang diajukan. Karena manusia senantiasa membutuhkan respons terhadap perkembangan zaman dan perubahan sosial budaya. ${ }^{2}$

Pada tataran praktis, terdapat dua bentuk fatwa yaitu fatwa individual (fardi) dan fatwa kolektif (jama’i). Secara sederhana fatwa kolektif dapat diartikan sebagai fatwa yang dikeluarkan oleh sekelompok orang atau sebuah organisasi yang memiliki wewenang dan kapasitas untuk mengeluarkan fatwa. Di Indonesia, lembaga yang produk fatwanya tergolong dalam kelompok fatwa kolektif adalah Komisi Fatwa MUI, Komisi Fatwa Dewan Dakwah Islamiyah Indonesia, Direktorat Pembinaan Peradilan Agama Islam Departemen Agama, Lembaga Bahsu al-Masail, Majelis Tarjih Muhammadiyah, dan lain-lain. Fatwa yang bersifat kolektif ini merupakan bentuk ijtihad moderen yang dianggap ideal. Fatwa kolektif dirumuskan berdasarkan berbagai sudut pandang ilmiah, sehinga dinilai lebih

\footnotetext{
${ }^{1}$ Iswahyudi, Majelis Ulama Indonesia dan Nalar Fatwa-Fatwa Eksklusif, (Jurnal Al-Ihkam Vol. 11 No. 2, Desember 2016), h. 55.

${ }^{2}$ Huzaemah T. Yanggo, Urgensi fatwa pada zaman sekarang, makalah disajikan dalam seminar Hukum Islam di Universitas Indonesia, (Depok, Jawa Barat tanggal 9 februari 2017).
} 
mendekati kebenaran. Pada konteks modern, ijtihad kolektif dianggap penting, karena permasalahan-permasalahan yang muncul saat ini semakin kompleks dan beragam. Untuk memecahkan permasalahan-permasalahan baru yang muncul dan semakin kompleks itu membutuhkan berbagai pendekatan. ${ }^{3}$

\section{METODE}

Penelitian ini bertujuan untuk mengkaji dan mengidentifikasi kaidah serta normanorma dalam hukum Islam, baik pada tataran metodologis, argumentasi (ushul fiqh) maupun pada tataran produk fikih, sehingga dikategorikan ke dalam penelitian hukum yang bersifat normatif (normative law). Penelitian hukum normatif mencakup kaidah dan pengertian yang biasa disebut dengan hukum dogmatik atau doktrinal. ${ }^{4}$

Penelitian ini menggunakan pendekatan ushul fikih dan secara khususa maqasid alsyariah, kaidah fikih dan perbandingan mazhab, serta menggunakan model penelitian kualitatif, karena tujuan utamanya adalah untuk mengembangkan konsep, mendeskripsikan realitas dan mengembangkan teori.

\section{PEMBAHASAN}

\section{Fatwa Perspektif Etimologi dan Terminologi}

Fatwa secara etimologi merupakan turunan dari kata afta yufti; yang berarti reaksi terhadap suatu peristiwa (event). Al-Zamakhsyari menyatakan dalam kitabnya al-Kasysyaf bahwa kata fatwa berasal dari kata al-fata yang artinya pemuda, ungkapan ini merupakan sebuah bentuk isti'arah (metafora). Dalam kamus Lisan al-'Arab, Ibnu Mandzur mengatakan: "aftahu fi al-amr, abanahu lahu" (memberikan fatwa kepada seseorang terhadap suatu permasalahan atau menjelaskannya), wa afta al-rajul fi al-mas'alah (Seorang laki-laki menjelaskan permasalahan), istaftaituhu fiha fa aftani ifta'an wa futwa (saya bertanya kepadanya tentang suatu masalah, maka dia menjawabnya) Perkataan wafata adalah asal dari kata futya atau fatwa. Futya dan fatwa adalah dua kata benda (isim) yang digunakan dengan arti al-ifta'. Ifta' berasal dari kata Iftay, yang artinya memberikan penjelasan. ${ }^{5}$

Sedangkan pengertian fatwa secara istilah adalah penjelasan hukum suatu masalah sebagai jawaban atas pertanyaan yang diajukan oleh mustafti (peminta fatwa) oleh seorang mufti atau lembaga fatwa. Mufti dan Mustafti bias bersifat individual ataupun kelompok.

\footnotetext{
${ }^{3}$ Ali Hasballah, Us \}ul al-Tasyri' al-Islami, (Mesir: Dar al-Ma'arif, 1976), h. 426.

${ }^{4}$ Johnny Ibrahim, Teori dan Metodologi Penelitian Hukum Normatif, (Malang: Bayu Media Publising, 2006), h.

${ }^{5}$ Amir Syarifuddin, Ushul Fiqh Jilid II, (Jakarta: Kencana, 2008) h. 484.
} 
Pengertan fatwa dalam KBBI mencakup dua hal: 1) Jawaban seorang mufti/ahli terhadap suatu pertanyaan yang diajukan, baik berupa keputusan ataupun pendapat; 2) Fatwa dapat diartikan sebagai nasihat orang alim, petuah, dan pelajaran baik. ${ }^{6}$ Sedangkan menurut Amir Syarifuddin fatwa merupakan upaya para ahli untuk memberikan penjelasan hukum syarak bagi yang tidak mengetahuinya. ${ }^{7}$ Dari ketiga definisi fatwa di atas dapat disimpulkan bahwa fatwa adalah jawaban seorang mufti atas suatu permaslaahan yang diajukan oleh mustafti. Fatwa harus didasarkan pada dalil-dalil syarak, sebab tidak boleh dalam Islam seseorang mengatakan halal dan haram tanpa didasari oleh dalil. Cakupan fatwa lebih khusus dibandingkan dengan fikih; sebab tidak semua fatwa yang dikeluarkan oleh seorang mufti merupakan sesuatu yang baru, boleh jadi jawaban mufti telah dirumuskan dalam fikih sebelumnya, hanya saja mustafti belum mengetahuinya. ${ }^{8}$ Dalam kajian ushul fikih, fatwa bersifat ikhtiyariyyah, merupakan pilihan yang tidak mengikat secara umum. Fatwa hanya mengikat bagi mufti dan mustafti, sedangkan bagi orang lain, fatwa bersifat i'lamiyyah atau informasi yang lebih dari sekedar wacana.'

Dalam kegiatan berfatwa dikenal beberapa istilah yaitu al-ifta atau al-futya, mustafti, mufti, mustafti fih dan fatwa. Al-Ifta atau al-futya, dapat diartikan sebagai kegiatan penafsiran hukum syarak dalam menanggapi pertanyaan yang diajukan; Mufti yaitu pihak yang mengeluarkan fatwa atau respons terhadap suatu permasalahan yang diajukan, mufti bias berupa individu atau kelompok; Mustafti yaitu individu atau kelompok yang meminta fatwa; Mustafti fih adalah permasalan yang dimintai fatwa atau jawaban, dimintai fatwa; dan fatwa adalah jawaban atau respons terhadap persoalan yang diajukan. ${ }^{10}$

\section{Syarat-Syarat Mufti dan Mustafti}

Menjadi seorang mufti tidaklah mudah. Setidaknya, ada berbagai syarat yang harus dipenuhi sebelum seseorang berfatwa. Jalaluddin al-Mahalli menyatakan bahwa terdapat tiga syarat yang harus dipenuhi oleh seorang mufti: 1) Menguasai kaidah fikih dan usul fikih; 2) Memiliki kemampuan untuk melaksanakan istinbat hukum; 3) menguasai ilmuilmu penunjang dalam merumuskan hukum, seperti ilmu nahwu, tafsir ayat-ayat hukum, ilmu mustalah al-hadis dan hadis-hadis ahkam. Senada dengan itu, al-Syaukani menyebutkan tiga syarat yang harus dipenuhi seorang mufti yaitu memiliki kemampuan untuk melaksanakan ijtihad, bersikap adil, dan menghindari kesan melonggarkan dan

\footnotetext{
${ }^{6}$ Tim Penyusun Kamus Pusat Pembinaan dan Pengembangan Bahasa, Kamus Besar Bahasa Indonesia,.. h. 240.

${ }^{7}$ Mardani, Ushul..., h 374-375.

${ }^{8}$ Ahyar A. Gayo, Kedudukan Fatwa MUI Dalam Upaya Mendorong Pelaksanaan Ekonomi Syariah, (Penelitian Hukum Badan Pembinaan Hukum Nasional Kementerian Hukum Dan HAM RI, 2011) h. 13.

${ }^{9}$ M. Zaidi Abdad, Signifikansi Fatwa DSN-MUI terhadap Perkembangan Ekonomi Syariah di Indonesia, (Istinbath: Jurnal Hukum dan Ekonomi Islam, Vol. 18, No. 2, 2019), h. 341.

${ }^{10}$ Nasrun Haroen, Ushul Fiqh, (Jakarta: Logos Wacana Ilmu, 2001), h. 203.
} 
menyederhanakan hukum. Sementara itu, al-Nawawi mengatakan bahwa mufti harus seorang yang bersifat warak, tsiqah, amanah, bebas dari sifat fasik, berpikiran tajam, sehat mental, dan sehat fisik. Mufti tidak harus bisa menjawab setiap pertanyaan, sebab ijtihad merupakan pekerjaan yang dapat terbagi-bagi. Seorang alim dapat dikatakan berijtihad meskipun hanya melakukannya dalam beberapa masalah, sebagaimana hal ini dikatakan oleh al-Ghazali. ${ }^{11}$

Fatwa memiliki urgensivitas dalam Islam, seorang mufti jika dihadapkan dengan suatu permasalahan hukum yang dimintai fatwa, maka baginya tidak boleh menolak. Menurut al-Nawai sebagaimana dikutip oleh Rachmat Syafe'i bahwa ada sejumlah perkara yang harus diperhatikan dalam fatwa, yaitu: 1) Hukum berfatwa adalah fardhu kifayah. Artinya, jika ada suatu permasalahan hukum yang harus dipecahkan, maka seorang yang mempunyai kompetensi dalam berfatwa harus memecahkan masalalah tersebut; 2) Jika seorang mufti telah mengeluarkan fatwa sebelumnya, kemudian fatwa tersebut dinilai kurang tepat, maka wajib bagi yang mengeluarkan fatwa untuk memberitahukan kepada peminta fatwa, bahwa fatwa yang dikeluarkan tidak tepat; 3) Seorang mufti tidak boleh terlalu memudahkan dalam berfatwa. Dan haram bagi seseorang untuk meminta fatwa kepada seorang mufti yang dikenal terlalu mudah dalam berfatwa; 4) Ketika berfatwa, seorang mufti harus dalam keadaan stabil, tidak dalam kadaan sakit secara jasmani dan rohani, sehingga dapat berfikir dengan jernih, dan dapat menjaga kenetralan dalam berfatwa; 5) fatwa memiliki kedudukan yang sangat tinggi dalam Islam, tidak selayaknya seorang mufti menjadikan fatwa sebagai kepentingan dirinya dan dijadikan sebagai sumber penghasilan; 6) Jika suatu permasalahan telah difatwakan sebelumnya, maka boleh bagi seorang mufti untuk menyampaikan jawaban tersebut kepada mustafti lainnya; 7) dalam berfatwa, seorang mufti hendaknya merujuk kepada sumber-sumber dan kitab-kitab yang mu'tabar; 8) Fatwa yang dikeluarkan oleh seorang mufti harus jelas dan dapat langsung diamalkan oleh mustafti. ${ }^{12}$

Dalam fatwa, selain terdapat syarat-syarat yang berkaitan dengan mufti yang harus dipenuhi, juga terdapat sejumlah syarat dan aturan yang harus dipenuhi oleh mustafti, yaitu: 1) Fatwa diminta oleh orang atau lembaga yang tidak dapat memecahkan masalah dengan sendirinya. Bagi orang atau lembaga yang dapat melakukan istinbat hukum secara mandiri tidak seharusnya meminta fatwa kepada orang lain; 2) Sebelum seseorang atau lembaga meminta fatwa, maka terlebih dahulu memastikan apakah seorang mufti yang akan dimintai fatwa mempunyai kemampuan untuk berfatwa; 3) Mustafti tidak diharuskan mengetahui jawaban yang akan disampaikan oleh seorang mufti adalah pendapat mazhab tertentu; 4) Ketika seorang mustafti mendapati dua fatwa yang berbeda dari mufti yang

\footnotetext{
${ }^{11}$ Nasrun Haroen, Ushul..., h. 206.

${ }^{12}$ Rachmat Syafe'i, Ilmu Ushul fiqih untuk UIN, STAIN, PTAIS, (Bandung: CV. Pustaka Setia, 2007) h. 177.
} 
berbeda pula, maka mustafti harus mendahulukan fatwa yang dikeluarkan oleh mufti yang lebih diakui secara luas dan lebih berkompeten. Jika tidak diketahui mana yang lebih berkompeten maka boleh memilih salah satu dari keduanya yang lebih aman; 5) Mustafti terikat dengan fatwa yang dikeluarkan oleh seorang mufti, jika tidak menemukan mufti lain; 6) Jika seorang mustafti menemukan suatu permasalahan yang pernah difatwakan, maka dalam hal ini ulama berbeda pendapat, sebagian berpendapat bahwa bagi mustafti dapat meminta fatwa kembali dengan alasan bahwa bias jadi fatwa yang akan dikeluarkan akan berbeda dengan yang difatwakan sebelumnya, sesuai dengan kondisi dan perkembangan zaman. Sedangkan sebagian ulama yang lain lebih memilih untuk tidak meminta fatwa kembali, melainkan dapat merujuk pada fatwa yang telah dikeluarkan sebelumnya; 7) Dianjurkan bagi seorang mustafti untuk mendatangi mufti secara langsung ketika ingin meminta fatwa; 8) Mustafti seyogyanya berperasangka baik serta berperilaku baik terhadap mufti; 9) Mustafti tidak seyogyanya menuntut seorang mufti untuk menyebutkan dalil-dalil yang dijadikan landasan dan argumentasinya; 10) Jika dalam suatu tempat mustafti tidak menemukan seorang mufti atau lembaga fatwa maka orang tersebut tidak terkena taklif. ${ }^{13}$

\section{Perbedaan Fatwa dengan Putusan Pengadilan}

Terdapat sisi persamaan antara fatwa dan al-qadha atau putusan pengadilan. Orang yang berperan aktif dalam mengeluarkan fatwa dan putusan pengadilan harus memiliki dua pengetahuan yaitu pengetahuan tentang hukum syarak dan peristiwa atau masalah yang akan difatwakan atau diberikan putusan pengadilan. Di samping terdapat sisi persamaan, keduanya mempunya sisi perbedaan yang sangat signifikan. Perbedaan antara fatwa dan putusan pengadilan dapat digambarkan sebagai berikut:

Perbedaan pertama, cakupan pemberi fatwa sangatlah luas jika dibandingkan dengan pemberi putusan pengadilan atau hakim. Menurut sebagian ulama, pemberi fatwa boleh seorang yang mempunyai hubungan kekerabatan dengan mustafti ataupun orang asing, baik seorang yang merdeka ataupun seorang hamba sahaya, laki laki ataupun perempuan. Berbeda dengan orang yang memberikan putusan pengadilan. Pemberi putusan pengadilan tidak boleh seorang yang mempunyai hubungan kekerabatan dengan orang yang bersangkutan, atau mempunyai hubungan persahabatan, hal ini guna menjaga kenetralan hakim. Di samping itu, pemberi putusan pengadilan harus bersetatus seorang yang merdeka, tidak boleh seorang budak belian;

Kedua, putusan suatu perkara yang dikeluarkan oleh seorang hakim bersifat mengikat bagi penggugat dan tergugat, sedangkan fatwa bersifat tidak mengikat, boleh diterima oleh mustafti atau menolaknya;

\footnotetext{
${ }^{13}$ Abdul Wahab Khalaf, Ilmu Ushulul Fiqh, (Bandung: Gema Risalah Press, 1997), cet.2, hal.157.
} 
Ketiga, perbedaan yang lain bahwa putusan pengadilan dapat menggugurkan pendapat seorang mufti yang tidak selaras. Sedangkan fatwa yang dikeluarkan oleh seorang mufti tidak dapat membatalkan putusan pengadilan, Putusan hakim bisa membatalkan pendapat mufti yg tidak selaras;

Keempat, seorang mufti tidak dapat memberikan putusan pengadilan, kecuali apabila bersetatus sebagai hakim, berbeda dengan hakim yang harus memberikan putusan pengadilan. $^{14}$

\section{Historiografi Majelis Ulama Indonesia}

Majelis Ulama Indonesia (MUI) dibentuk tepatnya pada tanggal 26 Juli tahun 1975 Masehi, yang bertepatan dengan tanggal 17 Rajab tahun 1395 Hijriyah. Dibentuk melalui sebuah Muktamar Nasional Ulama yang diadakan di Jakarta. Muktamar ini secara eksklusif dibuka oleh Presiden Soeharto. Dibentuknya lembaga ini merupakan bentuk perhatian pemerintah yang tinggi terhadap agama Islam yang dianut oleh mayoritas penduduk Indonesia. Berdasarkan sensus penduduk tahun 1971, sebanyak 87, 51 persen atau 103,57 juta jiwa penduduk Indonesia memeluk agama Islam. Besarnya kuantitas umat Islam merupakan potensi yang harus dikelola dengan sebagai pendukung laju kepemerintahan. ${ }^{15}$

Pada awal berdirinya, kantor MUI bertempat di salah satu ruangan Masjid al-Azhar. Bangunan kantor MUI tersebut atas donasi dari Menteri Agama, Menteri Luar Negeri (MENLU) serta donasi dari gubernur DKI Jakarta saat itu. Kemudian setelah Masjid Istiqlal diresmikan, kantor MUI berpindah ke kompleks Masjid Istiqlal. Kepengurusan MUI terdiri dari Pelindung, Dewan Pertimbangan serta Dewan Pimpinan. Saat itu, jabatan Pelindung diduduki oleh Presiden Republik Indonesia, jabatan Dewan Pertimbangan diduduki oleh Menteri Agama, dan Dewan Pimpinan pertama dijabat oleh Buya Hamka. Saat itu, MUI terdiri dari lima komisi, yaitu Komisi Fatwa, Komisi Kerukunan antar Umat Beragama, Komisi Ukhuwah Islamiyah, Komisi Kerjasama antar Ulama dan Umara, dan Komisi Umum. ${ }^{16}$

Institusi bentukan pemerintah orde baru ini dibentuk dengan tujuan sebagai sarana komunikasi antara pemeluk agama Islam dengan pemerintahan di samping dengan partai politik. Berbagai lapisan masyarakat tergabung dalam institusi ini, mulai dari para ulama,

\footnotetext{
${ }^{14}$ Abdul Fatah Idris, Menggugat Istinbath Hukum Ibnu Qayyim Studi Kritik Terhadap Metode Penetapan Hukum Ibnu Qayyim Al-Jauziyah, (Semarang: Pustaka Zaman, 2007), h. 32

${ }^{15}$ Mujibburahman, Feeling Threatened: Muslim-Christian Relation in Indonesia's New Order, (Amsterdam: Amsterdam University Press), h. 16.

${ }^{16}$ Jamal Ma'mur, Peran Fatwa MUI dalam Berbangsa dan Bernegara: Talfiq Manhaji sebagai Metodologi Penetapan Fatwa MUI, (Wahana Akademika: Vol 5, No. 2, Oktober 2018), h. 51.
} 
pemerintah, para cendekiawan muslim, tenaga ahli, organisasi keislaman dan forum-forum Islam, serta wanita dan para pemuda, yang merupakan perwakilan suara umat Islam. ${ }^{17}$

Tugas utama MUI adalah memberikan fatwa sebagai solusi keagamaan terhadap permasalahan-permasalahan yang muncul di tengah-tengan kehidupan masyarakat, memberikan nasihat dan seruan moral terhadap masyarakat muslim dan pemerintahan, baik persoalan yang menyangkut dengan keagamaan maupun problem bangsa secara umum. Selain itu, MUI juga bertugas untuk menjembatani nilai-nilai agama yang bersifat etis dan program-program pembangunan pada tataran praktis. Badan yang menghubungkan antara MUI dan pemerintahan adalah Departemen Agama (DEPAG) selaku badan yang mengurus masalah keagamaan di Indonesia. ${ }^{18}$ MUI tidak diperkenankan terlibat dalam politik praktis, dan kepentingan-kepentingan praktis. Oleh karena itu, MUI lebih dikenal di kalangan masyarakat dengan produk-produk fatwa yang dikeluarkannya. ${ }^{19}$

Permasalahan-permasalahan yang diajukan kepada MUI untuk dimintai fatwa sangat beragam. Fatwa MUI mempunyai kedudukan yang sangat tinggi di kalangan umat Islam, namun bersifat otoritatif, tidak mempunyai kedudukan konstitusional dalam sistem pemerintahan Indonesia. Hanya saja, fatwa yang dikeluarkan oleh MUI, diperlakukan seolah badan legislatif. MUI sangat diperhitungkan dalam agenda politik di Indonesia, sebagaimana dikatakan oleh Ricklefs, setidaknya sebagai representasi numat Islam di Indonesia. ${ }^{20}$

Tugas MUI sebagai pemberi fatwa bagi orang yang membutuhkannya telah dilaksanakan sejak berdirinya tahun 1975 hingga saat ini. Fatwa MUI diminta dari berbagai kalangan, baik yang bersifat individual ataupun forum pemerintahan. Permasalahan-permasalahan yang dimintai fatwa pun majemuk, mulai dari persoalan yang berkaitan dengan pribadi sampai masalah publik yang berkaitan dengan ibadah, sosial politik, sosial kemasyarakatan, persoalan halal atau haramnya makanan dan obat-obatan, masalah kedokteran, sampai persoalan ilmu pengetahuan dan teknologi. Sejarah MUI telah banyak dikaji oleh para sarjana dan ahli dari berbagai sudut pandang yang berbedabeda, sejak berdirinya pada tahun 1975 sampai dengan saat ini. ${ }^{21}$

\footnotetext{
${ }^{17}$ Majelis Ulama Indonesia (MUI), Himpunan Fatwa MUI Sejak 1975, (Jakarta: Penerbit Erlangga, 2015), h. V. Orde Baru lahir melalui kemelut politik Gerakan 30 September 1965 yang ditandai dengan munculnya Soeharto dalam politik nasional.

${ }^{18}$ Deliar Noer, Gerakan Moderen Islam di Indonesia 1900-1942, (Jakarta: LP3ES 1996) h. 30.

${ }^{19}$ Noer, Deliar, Gerakan Moderen Islam di Indonesia 1900-1942, (Jakarta: LP3ES).

${ }^{20}$ Ricklefs, M. C, Mengislamkan Jawa: Sejarah Islamisasi Jawa dan Penentangnya dari 1930 sampai Sekarang. Terj. FX. Dono Sunardi, (Jakarta: Serambi), h. 32.

${ }^{21}$ Majelis Ulama Indonesia (MUI), Himpunan Fatwa Keuangan Syariah Dewan Syariah Nasional MUI, (Jakarta: Penerbit Erlangga, 2014), h.V.
} 


\section{Analisis Metode Istinbath Hukum Majelis Ulama Indonesia}

Fatwa dalam Islam memiliki urgensivitas yang sangat tinggi, dalam memecahkan suatu masalah yang muncul di tengah-tengah masyarakat, dan dapat dijadikas sebagai alternatif yang dapat memecahkan kebekuan perkembangan hukum Islam. Masalah-masalah yang timbul di kalangan masyarakat semakin kompleks dan beragam seiring dengan perkembangan zaman dan perbedaan sosial budaya. Hukum Islam menghadapi masalah yang serius ketika ada suatu permasalahan yang tidak pernah ada sebelumnya. Dalam penetapan hukum Islam tidak dapat terlepas dari nas-nas keagamaan (al-nusus alsyar'iyyah) yang secara kuantitas telah berhenti, namun persoalan dan kasus senantiasa berkembang dan bermunculan. Nas-nas al-Qur'an dan hadis jumlahnya terbatas dan telah berhenti, sedangkan permasalahan-permasalahan terus berkembang dan bermunculan, sebagaimana yang dikatakan oleh para ulama. Maka dalam kondisi ini, fatwa dapat menjadi salah satu alternatif untuk mengurai persoalan-persoalan yang muncul tersebut. ${ }^{22}$

Fatwa harus ditetapkan berdasarkan metode, sebab penetapan fatwa yang tidak didasarkan dengan mengindahkan metode merupakan hal yang tidak dibolehkan dalam Islam. Fatwa yang ditetapkan hanya berdasarkan pada kebutuhan, atau sebab ada kemaslahatan dan maksud syariat, dan tanpa didasarkan pada nas-nas dari al-Qur'an dan hadis maka hal itu merupakan perbuatan yang kebablasan (ifrat). Sebaliknya, fatwa yang ditetapkan hanya berdasarkan nas-nas syarak tanpa memperhatikan kemaslahatan dan tujuan syariat, sehingga tidak dapat menjawab semua permasalhan yang muncul, maka hal tersebut juga tidak dibolehkan, hal ini termasuk pada sikap gegabah (tafrit).

Dalam perkembangan hukum Islam, kaidah istinbat hukum yang dapat dijadikan sebagai pedoman dalam penetapan fatwa yaitu metode bayani, ta'lili, dan istislahi. Metode bayani digunakan dalam berfatwa untuk menjelaskan teks-teks al-Qur'an dan hadis dari segi kebahasaan. Dalamkajian usul fikih, metode ini mencakup pembahasan tentang makna lafadaz, pemakaian lafaz, terang dan samarnya, dan penunjukan lafaz kepada maknanya. Metode ta'lili digunakan untuk menggali hukum suatu masalah yang tidak ditemukan dalilnya secara tersurat baik dalam al-Qur'an ataupun hadis nabi. Istinbat hukum dengan menggunakan metode ini yaitun untuk menggali suatu kasus baru dengan merujuk kepada kasus lama yang sudah ditetapkan hukumnya terlebih dahulu, dengan memperhatikan kesamaan 'illat hukumya. Sedangkan metode istislahi digunakan untuk menggali hukum suatu kasus baru yang ketentuan hukumnya tidak ditemukan dalam nas-nas syarak baik alQur'an ataupun hadis nabi, tidak ditemukan dalam ijmak ulama, dan tidak dapat

${ }^{22}$ Abdurrahman al-Jaziri, al-Fiqh 'ala al-Madzahib al-Arba'ah, ((Mesir: al-Maktabah al-Tijariyah al-Kubra, 1976), Vol. III, h. 41. 
diselesaikan dengan menggunkan kiyas dan istihsan, dengan mempertimbangkan kemaslahatan umum dan maqasid al-syari'ah. Metode Istislahi. ${ }^{23}$

Secara umum, ketiga metode di atas (bayani, ta'lili, dan istislahi) telah digunakan dalam penetapan fatwa MUI. Setiap fatwa yang dikeluarkan oleh MUI harus membawa kemaslahat bagi umat dengan didasarkan pada dalil-dalil yang kuat dan merupakan pendapat hukum. Hal ini sebagaimana tercantum dalam pedoman dasar penetapan fatwa MUI. Dalam menetapkan suatu ketentuan hukum, MUI terlebih dahulu merujuk kepada al-Qur'an, hadis nabi, ijmak ulama dan kiyas. Keempat dasar hukum ini telah disepakati oleh jumhur ulama. Dasar ilmiah dalam menetapkan suatu ketentuan hukum sebagaimana yang dikatakan oleh Imam al-Syafi'i adalah empat dalil tersebut, maka tidak semeskinya seseorang berbicara tentang halal dan haram tanpa didasari oleh dalil yang kuat. ${ }^{24}$ Senada dengan itu, Ibn Qayyim menyatakan bahwa keempat dalil tersebut merupakan dalil-dalil yang disepakati oleh para ulama, tidak ada perbedaan pendapat di kalangan ulama, sebab keempat dalil tersebut saling mendukung antara satu dengan yang lainnya dan saling membenarkan. ${ }^{25}$

Selain keempat dalil tersebut yang disepakati oleh para ulama, MUI juga menggunakan dalil-dalil yang mukhtalaf di kalangan ulama, seperti sad al-dzari'ah, istihsan, maslahah mursalah, istishab, dan dalil-dalil lainnya. Lebih lanjut lagi, dalam mengkaji suatu permasalahan MUI terlebih dahulu mencari pendapat imam mazhab dan ulama terdahulu, memperhatikan bentuk istidlalnya, dan dan kemudian menjadikannya sebagai pertimbangan dalam memutuskan hukum persoalan tersebut, juga mempertimbangkannya yang paling membawa maslahat bagi umat. Jika dalam suatu masalah hanya ditemukan satu pendapat ulama, maka MUI menjadikannya sebagai keputusan fatwa. Dan jika dalam suatu masalah ditemukan lebih dari pada satu pendapat ulama, maka MUI memilih salah satu pendapat ulama yang paling kuat dasarnya dan yang paling banyak membawa kemaslahatan bagi umat. Metode ini dikenal dengan metode tarjih. Secara sederhana, metode tarjih dapat diartikan dengan memilih suatu pendapat yang mempunyai dalil yang paling kuat dan menggunakannya, dan meninggalkan pendapat lain yang memiliki dalil yang lemah sebagaimana yang dikatakan oleh al-Razi dalam kitabnya al-Mahsul. Tarjih merupakan suatu keharusan, sebab tidak semua masalah ketetapan hukumnya menggunakan dalal yang bersifat qat'iy (absolut) melainkan banyak masalah-masalah yang ditetapkan hukumnya dengan menggunakan dalil zanniy (tidak absolut). Ketika suatu masalah ditetapkan dengan menggunakan dalil zanniy maka akan timbul perbedaan pendapat di kalangan ulama. Ketika terdapat banyak pendapat ulama dalam suatu

${ }^{23}$ Moh. Abu Zahrah, Ushul Fiqih, (Jakarta: Pustaka Firdaus, 2008), h.332-334.

${ }^{24}$ Muhammad bin Idris al-Syafi'i, al-Risalah (Beirut: Daar al-Kutub al-'Ilmiyyah, 1940) h. 37.

${ }^{25}$ Muhammad bin Abu Bakar Ayyub Ibn Qayyim, I'lam al-Muwaqqi' in 'an Rabbi al- 'Alamin (Beirut: Daar alJail, 1973) h. 33. 
ketentuan hukum, maka seorang mujtahid harus memilih salah satu dari pendapatpendapat tersebut untuk diamalkan. Proses penentuan pendapat yang paling kuat dalilnya dan lebih membawa kemaslahatan bagu umat ini lah yang disebut dengan metode tarjih. ${ }^{26}$

Sudah menjadi suatu kewajiban bagi sesorang muslim beramal dengan menggunakan dalal yang paling kuat, dan meninggalkan dalil-dalil yang lemah, sebagaimana hal ini dikatakan oleh mayoritas ulama berdasarkan ijmak sahabat. Para sahabat nabi sepakat untuk beramal dengan dalil yang lebih kuat dan mendahulukannya daripada dalil dalil yang lemah. Perbedaan pendapat dalam suatu masalah merupakan suatu keniscayaan sejak dahulu. Hal ini dapat tergambarkan pada beberapa riwayat yang saling bertentangan. Salah satu contoh perbedaan dalam riwayat adalah riwayat hadis tentang mandi junub. Dua hadis yang kontradisi antara hadis riwayat Aisyah dan riwayat Abu Hurairah. Hadis riwayat Aisyah menyatakan bahwa mandi wajib bagi suami istri setelah melakukan hubungan badan baik keluar mani (inzal) ataupun tidak, sementara itu hadis riwayat Abu Hurairah menyatakan bahwa mandi junub tidak wajib jika tidak inzal. Kemudian para sahabat nabi memilih hadis riwayat Aisyah karena dinilai lebih rajah dibandingkan hadis riwayat Abu Hurairah dengan alasan bahwa Aisya lebih tahu perihal rumah tangga Rasulullah. Jika beramal dengan dalil yang paling kuat tidak dibutuhkan, maka para sahabat tidak akan melakukan tarjih terhadap dalil-dalil yang dinilai bertentangan. ${ }^{27}$

Berbeda dengan pendapat di atas, sebagian ulama menyatakan bahwa jika terdapat dua dalil yang saling bertentangan maka tidak perlu mentarjih salah satu dari keduanya, melainkan dihadapkan dengan dua pilihan, mengambil salah satu dalil yang ia inginkan tanpa mempertimbangkan mana yang lebih kuat atau tidak melanjutkan proses ijtihadnya. Pendapat ini didasarkan pada kandungan surat al-Hasyr ayat dua yang berisi perintah bagi orang-orang yang berakal untuk mengambil pelajaran. Perintah tersebut bersifat umum tidak ada perbedaan terhadap dalil yang kuat dan dalil yang lemah, dan tidak ada penghususan untuk mengambil dalil yang lebih kuat. Sementara itu al-A<midi berpendapat lain terhadap ayat tersebut, ia menyatakan bahwa ayat tersebut tidak bertentangan dengan perintah untuk mengambil pendapat yang paling kuat, karena ayat ayat tersebut menagndung perintah untuk berfikir secara umum. ${ }^{28}$

Dalam melakukan tarjih, seorang mujtahid hendaknya memperhatikan hal-hal berikut: 1) Metode tarjih tidak dapat digunakan pada dalil-dalil yang bersifat qat'i

\footnotetext{
${ }^{26}$ Fakhru al-Din Muhammad bin Umar al-Husain al-Razi, al-Mahshul fi ilmi al-Ushul, (Riyadh: Jami'ah alImam Muhammad bin Saud, 1400 H), h. 397.

${ }^{27}$ Muhammad Ibrahim Muhammad Al-Hifnâwi, al-Ta'arudh wa al-Tarjih 'inda al-Ushuliyyin wa Atsaruhuma fi al-Fiqh al-Islâmiy, (Mansura: Daar al-Wafâ li al-Thiba' ah wa al-Nasyr wa al-Tauzi’, 1987), h. 60.

${ }^{28}$ Saif al-Din Ali bin Ali bin Muhammad bin Sâlim al-Aamidi, al-Ihkam fi Ushul al-Ahkam (Kairo: Maktabah Shubaih, 1387 H) h. 257.
} 
(absolut), sebab dalil-dalil yang bersifat qat'i tidak melahirkan perbedaan pendapat. Jika tidak ada perbedaan, maka tarjih tidak dapat dilakukan. Dua dalil yang bersifat qat'i baik dalil naqli ataupun dalil 'aqli tidak akan saling bertentangan, jika terjadi pertentangan maka salah satunya menasakh dalil yang lain, dan jika salah satu dalil bersifat qat'i dan yang lain zanni maka otomatis dalil yang bersifat qat'i didahulukan ${ }^{29}$; 2) Bahwa metode tarjih digunakan jika tidak dapat menempuh jalan al-jam'u wa al-taufiq (mengompromikan dua dalil yang saling bertentangan). Jalan kompromi lebih baik daripada tarjih. Karena dengan mengompromikan dua dalil yang saling bertentangan berarti mengamalkan kedua dalil, dan mengamalkan kedua dalil lebih baik daripada mengamalkan salah satu dalil dan mengabaikan dalil yang lain. Hal ini berbeda dengan pendapat mazhab Hanafi yang berpendapat bahwa tarjih lebih baik dibandingkan al-jam'u' ${ }^{30}$; 3)Metode tarjih dalam prosesnya seorang mujtahid melihat kuantitas dalil yang digunakan, semakin banyak dalil yang digunakan, atau semakin banyak dalil yang mendukungnya maka semakin kuat suatu pendapat. Dan jika ada dua dalil yang saling bertentangan, kemudian ditemukan dalil lain yang mendukung salah satu dalil yang saling bertentangan tersebut, maka dalil ketiga ini dapat dianggap sebagai tarjih. ${ }^{31}$

Selanjutnya, jika pada suatu masalah tidak ditemukan pendapat ulam terdahulu, maka MUI menempuh metode ilhaq al-masail bi nazairiha (menganalogikan masalah baru yang tidak ditemukan keterangan hukumnya dalam nas dengan masalah serupa yang sudah ada hukumnya), dengan memperhatikan unsur-unsur berikut: 1) Masalah yang belum dibahas ulama (mulhaq bih); 2) Masalah yang sudah dibahas ulama (mulhaq 'alaih); 3) Dan bentuk persamaan antara mulhaq bih dan mulhaq 'alaih, atau yang dikenal dengan wajh al-ilhaq. Metode ini dikenal dengan sebutan takhrij. secara sederhana takhrij dapat diartikan dengan menganalogikan suatu masalah baru yang belum dibahas oleh ulama terdahulu dengan masalah yang sudah dibahas dan telah ditetapkan hukumnya terdahulu. Istilah takhrij ini lebih banyak digunakan oleh para pengkaji hadis sedangkan dalam istilah usul fikih sering dikenal dengan istilah ilhaq atau kiyas. Dalam kajian usul fikih, takhrij dapat dikalsifikasikan menjadi tiga macam: 1)Takhrij al-ushûl min al-furû'. Yaitu menemukan dasar-dasar yang digunakan oleh imam mazhab dalam menetapkan hukum Islam, dengan cara mengumpulkan dan mengamati produk fikihnya. Takhrij jenis ini lebih popular di kalangan mazhab Hanafi, sebab Abu Hanifah di masa hidupnya tidak mewariskan dasardasar ijtihadnya kepada para muridnya, sehingga para penerus mazhabnya lah yang merumuskan metode ijtihadnya dengan mengkaji produk fikih yang dihasilkan; 2) Takhrij

\footnotetext{
${ }^{29}$ Syihab al-Din Ahmad bin Qasim al-'Abbadi. al-Ayat al-Bayyinat 'ala Syarh Jam'i al-Jawami' (Kairo: AlMathba'ah al-Kubra, 1356 H) h. 148.

${ }^{30}$ Muhammad Salam Madkuur, Ushul al-Fiqh al-Islâmiy (Kairo: Dar al-Nahdhah al-'Arabiyah, 1395 H) h. 321.

${ }^{31}$ Abdul Rahim bin al-Hasan bin Ali al-Isnawi, Nihayat al-Sul Syarh Minhaj al-Wushul (Beirut: Daar al-Kutub al-'Ilmiyyah, 1999) h. 164 .
} 
al-furû' 'ala al-ushûl. Menurut kajian usul fiqih dapat diartikan dengan ilmu yang membahas tentang 'illat (alasan dasar) atau sumber-sumber hukum syarak yang dijadikan sebagai rujukan hukum-hukum furu' (cabang) untuk menjelaskan sebab-sebab berbedanya para ulama, atau menjelaskan hukum yang tidak terdapat pada literature imam mazhab baik pada kaedah fiqih atau ushul fiqih mereka ${ }^{32}$ 3) Takhrij al-furû' 'ala al-furû'. Yaitu menganalogikan sebuah masalah yang belum diketahui hukumnya dengan masalah lain yang serupa yang telah diketahui hukumnya untuk kemudian disamakan hukum keduanya. Takhrij model ini sering digunakan oleh ulama kontemporer dalam menghadapi permasalahn-permasalahn baru yang muncul akhir-akhir ini. Banyak masalah baru yang muncul seiring dengan perkembangan zaman dan perbedaan sosial budaya, dan semua masalah ini membutuhkan kepastian hukum syarak. Takhrij model ini juga digunakan oleh MUI dalam penetapan fatwa-fatwanya. ${ }^{33}$

Selanjutnya, jika dalam suatu masalah tidak dapat dipecahkan dengan metode takhrij, maka jalan terakhir yang ditempuh oleh MUI adalah dengan melakukan ijtihad jama’i (ijtihad kolektif). Ijtihad kolektif dilakukan dengan menggunakan kaidah-kaidah usul fikih dan kaidah fikih, serta mempertimbangkan maslahat umat Islam. Menurut alGhazali maslahat adalah menjaga tujuan syarak, dan tujuan syarak yang ingin dicapai dari makhluk adalah menjaga agama, jiwa, akal, keturunan dan harta mereka. Lima perkara ini dikenal dengan sebutan al-darurat al-khamsah. Setiap hukum syarak yang menjaga lima hal ini disebut dengan maslahat, dan setiap hal yang meniadakan kelima hal ini disebut dengan mafsadah atau kerusakan, dan menolak kerusakan adalah kemaslahatan. ${ }^{34}$

Al-Syatibi dalam kitabnya al-Muwafaqat menyatakan bahwa setiap dasar agama yang tidak ada keterangan nasnya secara langsung, namun sejalan dengan tujuan syarak, maka hal tersebut dibenarkan, dan dapat dijadikan sebagai dasar penetapan hukum syarak, jika kemaslahatan dapat dipastikan keberadaannya. Sebab dalil-dalil syarak tidak seluruhnya menunjukkan kepada kepastian hukum secara mandiri tanpa disandingkan dengan dalildalil yang lainnya. ${ }^{35}$

Terkait dengan maslahat, MUI menentukan tiga butir kriteria maslahat, yang pertama bahwa yang dimaksud dengan maslahat dalam Islam adalah tercapainya maqasid al-syari'ah atau maksud dan tujuan diturunkannya syariat Islam, yang diwujudkan dengan tercapainya lima kebutuhan pokok atau yang dikenal dengan al-daruriyat al-khams; Kedua, kriteria maslahat yang dibenarkan oleh syariat adalah kemaslahatan yang tidak

\footnotetext{
${ }^{32}$ Ya'qub bin Abdul Wahab al-Bahsain, al-Takhrij 'inda al-Fuqaha' wa al-Ushuliyyin, Dirâsah Nazhariah Tathbiqiyyah Ta'shiliyyah (Riyadh: Maktabah al-Rusyd, 1414 H), h. 51.

${ }^{33} \mathrm{Abu}$ al-Barakât Abdu al-Salâm Ibn Taimiyah, al-Musawwadah fi Ushul al-Fiqh (Riyadh: Dâr al-Fadhilah, 2001) h.948.

${ }^{34}$ Al-Ghazâli, Muhammad bin Muhammad. Al-Mustashfâ (Beirut: Dâr al-kutub al-'ilmiyyah, 1993) hal. 175.

${ }^{35} \mathrm{Al}$-Syâthibi, Abu Ishâq Ibrahim bin Musâ bin Muhammad. Al-Muwâfaqât (Riyadh: Dâr Ibn al-Qayyim, 2003), h. 93.
} 
bertentangan dengan nas-nas syarak; Dan ketiga, yang mennetukan suatu maslahat adalah lembaga yang mempunyai kompetensi di bidang hukum Islam dan dilakukan dengan ijtihad secara kolektif. ${ }^{36}$

\section{PENUTUP}

Dari uraian pembahasan di atas, dapat disimpulkan bahwa secara istilah fatwa dapat diartikan sebagai penjelasan seorang mufti (baik individu atau kelompok) terhadap hukum syarak, sebagai jawaban permasalan yang diajukan oleh seorang mustafti kepada mufti, baik secara individual maupun kolektif, atau sebagai respons terhadap suatu permasalahan. Dalam Islam, fatwa memiliki kedudukan yang sangat tinggi. Fatwa dapat dijadikan sebagai salah satu alternatif dalam memecahkan kebekuan perkembangan hukum Islam.

Dalam memecahkan permasalahan-permasalalahan kontemporer yang terjadi di tengah-tengah masyarakat, Majelis Ulama Indonesia (MUI) terlebih dahulu merujuk kepada nas-nas al-Quran dan hadits. Jika tidak ditemukan jawaban atas masalah tersebut, maka selanjutnya merujuk kepada ijmak ulama. Dan jika tidak ditemukan jawabannya, maka usaha selanjutnya menggunakan kiyas dan merujuk kepada dalil-dalil hukum yang mukhtalaf, (diperselisihkan di kalangan ulama), antara lain: sad al-dzarai', Istishab, maslah\{ah al-mursalah, istihsan, serta dalil-dalil lainnya.

Lebih lanjut, dalam membahas suatu persoalan, MUI terlebih dahulu memperhatikan pendapat para ulama mazhab. Jika dalam suatu masalah ditemukan hanya satu pendapat ulama saja, maka MUI menjadikannya sebagai keputusan fatwa. Namun, jika dalam suatu permasalahan terdapat lebih dari satu pendapat ulama, maka MUI memilih satu pendapat yang dinilai lebih rajih dengan menggunakan metode tarjih. Selanjutnya jika pada suatu masalah tidak ditemukan pendapat ulama terdahulu, maka MUI menganalogikan dengan masalah yang serupa atau dikenal dengan metode takhrij atau ilhaq al-masail bi nazha'iriha jika memungkinkan. Dalam praktiknya, Metode takhrij ini ditempuh dengan memperhatikan tiga komponen dasar yaitu mulhaq 'alaih, mulhaq bih, dan wajh al-ilhaqnya. Jika metode takhrij tidak dapat ditempuh maka MUI melakukan ijtihad jama’i.

\section{DAFTAR PUSTAKA}

Abdul Fatah Idris, Menggugat Istinbath Hukum Ibnu Qayyim Studi Kritik Terhadap Metode Penetapan Hukum Ibnu Qayyim Al-Jauziyah, (Semarang: Pustaka Zaman, 2007).

Abdul Wahab Khalaf, Ilmu Ushulul Fiqh, (Bandung: Gema Risalah Press, 1997), cet.2..

\footnotetext{
${ }^{36}$ Surat Keputusan Nomor: 6/MUNAS VII/MUI102005.
} 
Ahyar A. Gayo," Kedudukan Fatwa MUI Dalam Upaya Mendorong Pelaksanaan Ekonomi Syariah", Penelitian Hukum Badan Pembinaan Hukum Nasional Kementerian Hukum Dan HAM Ri, 2011.

Al-'Abbâdi, Syihâb al-Din Ahmad bin Qâsim. Al-Ayât al-Bayyinât ala Syarh Jam'I al-Jawâmi' (Kairo: Al-Mathba'ah al-Kubra, $1356 \mathrm{H}$ ).

Al-Aâmidi, Saif al-Din Ali bin Ali bin Muhammad bin Sâlim. Al-Ihkâm fi Ushul al-Ahkâm (Kairo: Maktabah Shubaih, $1387 \mathrm{H}$ )

Al-Bahsain, Ya'qub bin Abdul Wahab. Al-Takhrij 'inda al-Fuqaha' wa al-Ushuliyyin, Dirâsah Nazhariah Tathbiqiyyah Ta'shiliyyah (Riyadh: Maktabah al-Rusyd, $1414 \mathrm{H}$ ).

Al-Ghazâli, Muhammad bin Muhammad. Al-Mustashfâ (Beirut: Dâr al-kutub al'ilmiyyah, 1993)

Al-Hifnâwi, Muhammad Ibrahim Muhammad. Al-Ta'ârudh Wa al-Tarjih 'inda al-Ushuliyyin wa Atsaruhumâ fi al-Fiqh al-Islâmiy (Mansura: Dâr al-Wafâ li al-Thibâ'ah wa al-Nasyr wa al-Tauzi', 1987).

Al-Isnawi, Abdul Rahim bin al-Hasan bin Ali. Nihâyatu al-Sul Syarh Minhâj al-Wushul (Beirut: Dâr al-Kutub al-'Ilmiyyah, 1999).

Al-Razi, Fakhru al-Din Muhammad bin Umar al-Husain. Al-Mahshul fi ilmi al-Ushul. (Riyadh: Jâmi'ah al-Imâm Muhammad bin Saud, 1400 H).

Al-Syâfi'i, Muhammad bin Idris. Al-Risâlah (Beirut: Dâar al-Kutub al-'Ilmiyyah, 1940).

Al-Syâthibi, Abu Ishâq Ibrahim bin Musâ bin Muhammad. Al-Muwâfaqât (Riyadh: $\quad$ Dâr Ibn al-Qayyim, 2003).

Amir Syarifuddin, Ushul Fiqh Jilid II, (Jakarta: Kencana, 2008).

Brackman, Arnold C. 1970. The Communist Collaps in Indonesia. (Singapore: Asia Pasific Press).

Ibn Qayyim, Muhammad bin Abu Bakar Ayyub. I'lâm al-Muwaqqi'in 'an Rabbi al'Alamin (Beirut: Dâr al-Jail, 1973).

Ibn Taimiyah, Abu al-Barakât Abdu al-Salâm. Al-Musawwadah fi Ushul al-Fiqh (Riyadh: Dâr al-Fadhilah, 2001).

Indonesia’s New Order. Amsterdam: Amsterdam University Press

Madkuur, Muhammad Salâm. Ushul al-Fiqh al-Islâmiy (Kairo: Dâr al-Nahdhah al'Arabiyah, $1395 \mathrm{H})$.

Mardani, Ushul Fiqh, (Jakarta: Raja Wali, 2013).

Moh. Abu Zahrah, Ushul Fiqih, (Jakarta: Pustaka Firdaus, 2008).

Nasrun Haroen, Ushul Fiqh (Jakarta: Logos Wacana Ilmu, 2001).

Noer, Deliar. 1996. Gerakan Moderen Islam di Indonesia 1900-1942. (Jakarta: LP3ES).

Rachmat Syafe'i, Ilmu Ushul fiqih untuk UIN, STAIN, PTAIS, (Bandung: CV. Pustaka Setia, 2007).

Ricklefs, M. C. 2013. Mengislamkan Jawa: Sejarah Islamisasi Jawa dan Penentangnya dari 1930 sampai Sekarang. Terj. FX. Dono Sunardi (Jakarta: Serambi).. 